\author{
Szarvas Dávid, Tichy Roland, Rohács Dániel
}

\title{
MESTERSÉGES INTELLIGENCIA ALKALMAZÁSA AZ AVIATIKÁBAN
}

DOI: $10.32560 /$ rk.2019.1.15

\begin{abstract}
A mesterséges intelligencia és különbözö területei, mint a gépi tanulás, vagy a mély tanulás az utóbbi évek során nagy átalakuláson mentek keresztül. Bár az alapelvek már több mint 60 éve léteznek, a világban manapság rendelkezésre álló hatalmas mennyiségü és könnyen elérhetö adatmennyiség elömozditotta az alkalmazásukat az élet szinte minden területén. Cikkünk első részében egy átfogó képet kivánunk adni a mesterséges intelligencia fogalmáról, müködéséröl és csoportositásáról, valamint ismertetjük azokat a világméretü trendeket, amelyek ennek a tudományterületnek formálják a jelenét és jövöjét. A második részben pedig a legfontosabb aviatikai alkalmazásokon keresztül (többek között a légiforgalmi irányitással és forgalmi elörejelzéssel kapcsolatos alkalmazások) mutatjuk be a technológiában rejlö lehetöségeket, valamint azok felhasználásának hosszabb távú elképzeléseit.
\end{abstract}

Kulcsszavak: mesterséges intelligencia, gépi tanulás, elörejelzés, SESAR, ATM, adatelemzés

\section{BEVEZETÉS}

Már magát az intelligenciát is elég bonyolult akár mérni, akár egyértelmüen definiálni, mégis az embert folyamatosan foglalkoztatja annak minél mélyebb működése, megismerése. Mára viszont ott tartunk, hogy a mesterséges intelligencia (MI) vagy angolul Artificial Intelligence (AI) már teljesen a hétköznapok részévé vált. Akár arra gondolunk, hogy kb. olyan gyakorisággal említik a médiában, mint Elon Muskot, akár arra, hogy tudtunk nélkül is, de mára az életünk megkerülhetetlen része. Benne a van a telefonunk kamerájában, figyeli a fényképezési szokásainkat, hogy ezek alapján válasszon nekünk jobb beállításokat, a legnagyobb videomegosztó oldalon figyeli a preferenciáinkat, hogy ez alapján érje el, hogy minél több időt töltsünk el az adott platformon, személyi asszisztensként segíti a mindennapjainkat, vagy a közösségi oldalakon figyeli az érdeklődésünket. Akár az okostelefonunkat használjuk, az internetet böngésszük, on-line vásárolunk, navigációs rendszert használunk, a közösségi oldalakat nézzük, vagy streaming szolgáltatást használunk, legyen az zene vagy video, a mesterséges intelligencia befolyással van a döntési lehetőséginkre [1].

\section{IS AZ A MESTERSÉGES INTELLIGENCIA?}

\section{Definíció}

A probléma, hogy még a szakma sem rendelkezik egyértelmü állásponttal, azzal kapcsolatban, hogy mi is tartozik a MI témakörébe és mi nem. Ennek okai a következők:

1. Mostanáig nem született egységes hivatalos definíció. Ahogyan fejlődik a terület, (1. ábra) úgy írják újra, módosítják a meghatározást. Közérthetően megfogalmazva: „menő dolgok, amit a számítógépek csinálnak". A dolog iróniája, hogy épp az ellenkezője igaz. Vagyis a számítógépek nem számolással, hanem ,intelligenciával” logikai kapcsolódások feltárását célozzák meg. Ugyanis, amint logikailag fel tudjuk építeni a feladat megoldását szimpla számítási kapacitás segítségével már el is veszti egy kicsit az intelligencia jellegét 
és MI helyett inkább statisztikai vagy valószínűségszámítási kihívássá válik. Ötven évvel ezelött az útvonaltervezés is MI-nek számított. Egy elfogadottabb definíció szerint a MI egy olyan számítógép, ami valamilyen módon utánozza az emberi viselkedést.

2. Ami egyszerünek tünik az valójában bonyolult és fordítva. Azt is bonyolult feltérképezni a kutatók számára, hogy az MI számára mely feladatok egyszerűek és melyek nehezek (mert egy embert többnyire a feladatok elvégzése alapján ítélünk intelligensnek). Például ha azt a feladatot kapjuk, hogy vegyük fel az első tárgyat, ami kezünk ügyébe akad, az nekünk nem jelent nehézséget, de gondoljuk csak végig mi is zajlott le pontosan. Használtuk a szemünket, amivel beazonosítottuk a tárgyat, annak alakját és tömegét, eldöntöttük melyik kezünkkel emeljük meg a tárgyat, milyen úton érjük el, milyen erősséggel fogjuk az ujjaink közé. Ellenben például a sakkot egy bonyolult játéknak tartjuk, viszont a mesterséges intelligencia számára csak egyszerủ számítási feladat.

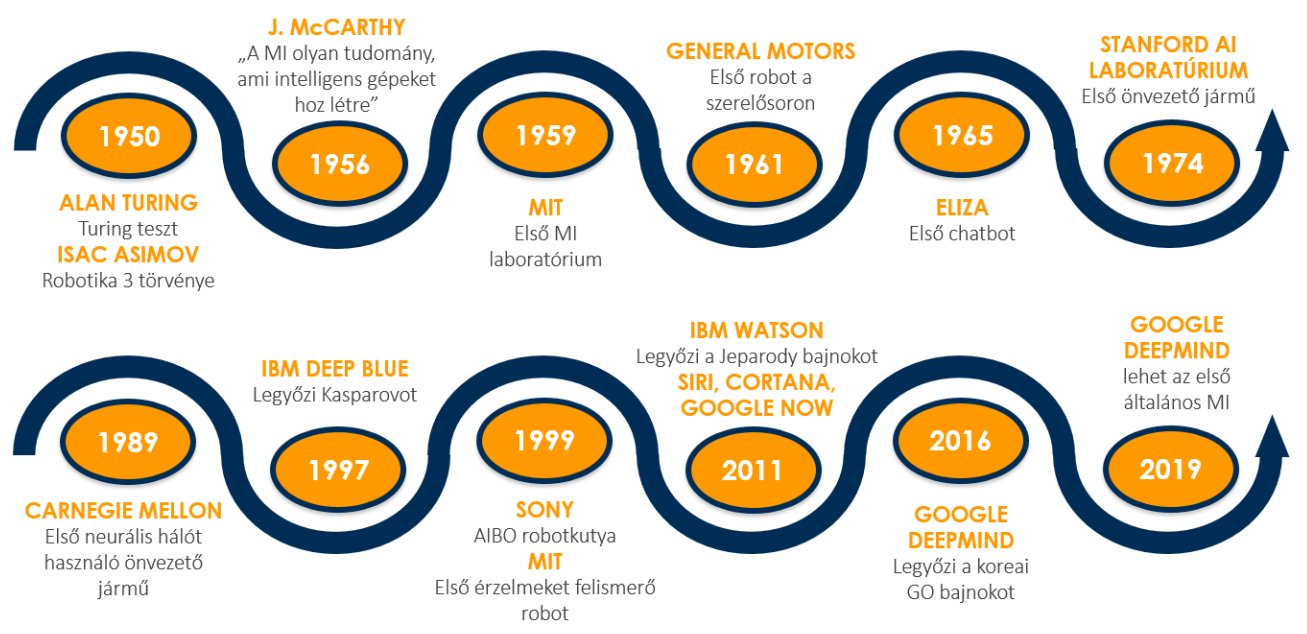

1. ábra A MI fejlödésének mérföldkövei [2]

Fontos, hogy megértsük, hogy az intelligencia nem egy egy dimenziós változó, mint például az IQ mellyel az embereket lehet intelligenicaszint alapján rangsorolni. Vajon tudnánk egy változóval rangsorolni az MI-t? Egy sakk algoritmus intelligensebb egy spamszürőnél, egy zeneajánló rendszernél vagy egy önvezető autónál? Egyértelműen nem, általában ezért beszélünk szűk mesterséges intelligenciáról ( $\left.\mathrm{ANI}^{1}\right)$ ami képes megoldást adni egy adott típusú problémára, de tehetetlen egy másik problémával szemben. Mivel nincs egyértelmü, jól körülhatárolható definíció, így a MI mindenkinek egy kicsit mást jelent. Néhány embernek egy olyan életforma, ami túlszárnyalja az emberi intelligenciát, mások szinte minden adatfeldolgozó technológiát MI-nek hívnak [3] [4].

\section{A MI csoportosítása}

A tudományterület kiforratlansága miatt sokan sokféle csoportosítási lehetőséget felvázoltak már. Az alábbiakban két lehetséges csoportosítást mutatunk be:

\section{Az intelligencia fejlettsége szerint (2. ábra):}

1. Szűk mesterséges intelligencia (ANI): csak egy szük problémára és annak megoldására fókuszál előre definiált keretrendszer alapján. Tipikusan repetitív feladatok elvégzésére alkalmas és ezeken a területeken jobban is teljesít, mint az ember. Szinte minden MI

\footnotetext{
${ }^{1}$ ANI - Artificial Narrow Intelligence - Szűk mesterséges intelligencia
} 
algoritmus, amit ma ismerünk, ebbe a kategóriába tartozik. Ez az a terület, ami az elmúlt időszakban ugrásszerüen fejlődött.

2. Általános mesterséges intelligencia $\left(\mathrm{AGI}^{2}\right)$ : ,gondolkodó” $\mathrm{MI}$, ami tanul a múltbeli tapasztalataiból és azok alapján hoz döntéseket.

3. Mesterséges szuperintelligencia $\left(\mathrm{ASI}^{3}\right)$ : ettől szinttől még messze vagyunk, de a koncepció egy olyan MI létrehozása, aminek a kognitív képességei az embernél fejlettebbek.

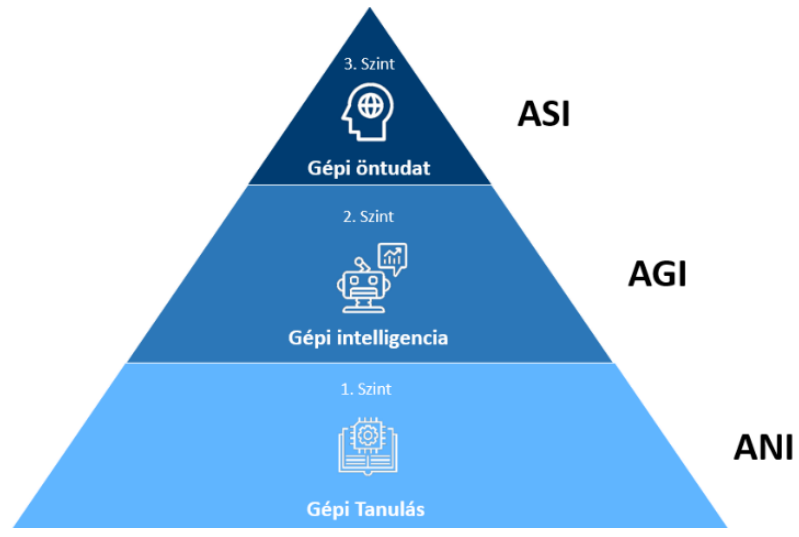

2. ábra A MI fejlettségi szintjei [5]

\section{Funkcionalitás szerint:}

1. Reaktív gépek: a MI egyik alapvető formája, amely nem rendelkezik memóriával és nem tud múltbeli eseményekre támaszkodni. Például ilyen az IBM DeepBlue ami a sakktáblát „látja” és reagál rá, de nem képes fejlődni.

2. Limitált memória: képes múltbeli események alapján döntést hozni. Többek közt az önvezető járműveknél használják. A döntéshez szükség van közelben lévő járművek helyzetére, sebességére, távolságukra. Ám a forgalmi helyzet elmúlásával, ezek a megfigyelések hosszútávon nem tárolódnak.

3. Tudatelmélet (Theory of Mind): képes megérteni az ember érzelmeit, elképzeléseit és szociális interakcióba lépni.

4. Öntudat (Self-awareness): az MI teljes öntudattal, érzelmekkel rendelkezik. Egyszóval egy emberi lény. Természetesen ilyen MI nem létezik, de ez következő feltételezett mérföldkő [6] [7] [8].

\section{A mesterséges intelligencia megvalósítása}

A továbbiakban, ebben a cikkben a mesterséges intelligenciára, a már említett definíciót használjuk, miszerint a MI egy olyan számítógép, ami valamilyen módon utánozza az emberi viselkedést. Ezt az utánzást többféleképpen lehetséges megvalósítani (3. ábra).

1. Gépi tanulás $\left(\mathrm{ML}^{4}\right)$ : ennél a típusnál a cél elöre meghatározott és az ahhoz szükséges lépésekre a gépnek folyamatos tanulás folyamán kell rájönnie. Ez azt jelenti, hogy a számítógépek olyan feladatokat hajtanak végre, amikre nem explicit lettek programozva. Az elv lehetővé teszi, hogy a számítógépes rendszerek ,tapasztalatokat szerez-

\footnotetext{
${ }^{2}$ AGI - Artificial General Intelligence - Általános mesterséges intelligencia

${ }^{3}$ ASI - Artificial Super Intelligence - Mesterséges szuperintelligencia

${ }^{4}$ ML - Machine Learning - Gépi tanulás
} 
zenek" ezzel egyidejüleg javuljanak és hatékonyabban elvégezzék a rájuk bízott feladatot. Például ahhoz, hogy egy gép felismerje, hogy egy adott képen alma vagy narancs látható nem kell egy alma vagy egy narancs definícióját konkrétan megadnunk, hanem - mint egy gyerek esetében - elég több (általában több millió) különböző képet mutatunk almákról és narancsokról. A mély tanulás $\left(\mathrm{DL}^{5}\right)$ a gépi tanulás részhalmaza, ami elérhetővé teszi a számítógépek számára a mélyebb problémák megoldását is. (a „mélység" a matematikai modell komplexitására utal). A gépi tanulás és mély tanulás MI-hez való kapcsolódását és időbeni fejlődését jól szemlélteti a 4. ábra [9] [10] [11] [12].

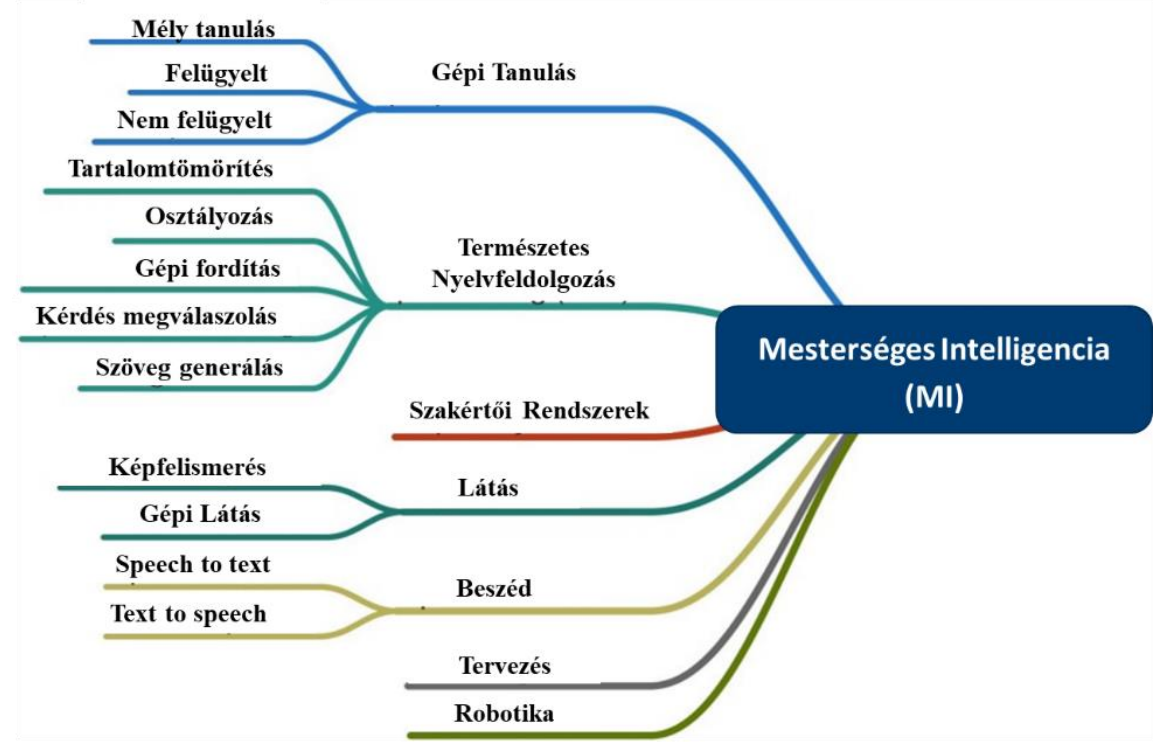

3. ábra A MI létrehozásának lehetséges módjai [6]

1. Nyelvfelismerés $\left(\mathrm{NLP}^{6}\right)$ : akár írott, akár beszélt szöveg alapján. Például így vannak megvalósítva a spamszürők.

2. Gépi látás: a gép a kamera képét digitalizálja, annak segítségével „lát” és elemez. Egyaránt alkalmazható mozgó és állóképre is.

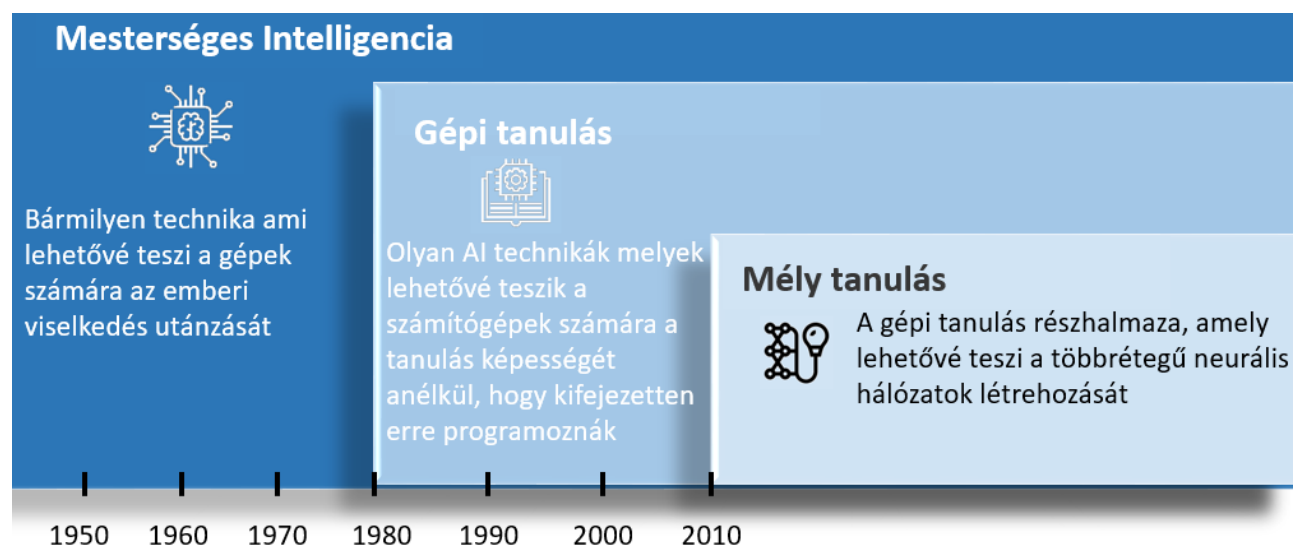

4. ábra A mesterséges intelligencia, a gépi tanulás és a mély tanulás kapcsolata [12]

\footnotetext{
${ }^{5}$ DL - Deep Learning - Mély tanulás

${ }^{6}$ NLP - Natural Language Processing - Nyelvfelismerés
} 
3. Robotika: ez a terület a robotgyártásra fókuszál, de a skála nagyon széles, az ,egyszerü” jármüösszeszerelő robottól egészen az emberi interakcióra képes robotokig tart. Általában olyan feladatokra használjuk, amelyek túl fárasztók, vagy túl monotonok lennének az ember számára.

4. Önvezető jármüvek: mostanában ez a terület kapja a legkiemeltebb figyelmet, mivel több területen is ugrásszerü a fejlödés az autóktól, buszoktól a hajókon át a drónokig, amelyekre a későbbiekben még kitérünk [5] [6].

\section{Mesterséges intelligencia trendek a világban}

Általánosságban, napjainkban még az ANI korát éljük, amely intelligencia ugyan sok részterületen messze felülmúlja az ember határait, mégis csak apró részfeladatokra képes fókuszálni. A jövőben azonban megjelenhet az AGI, ami már az emberhez hasonló intelligenciával rendelkezik. Egyesek szerint a Google DeepMind már megfelel ennek a kritériumnak, mások szerint örülhetünk, ha még a mi életünkben sikerül megalkotni az első általános mesterséges intelligenciát. Az ezt követő lépés az ASI, ami minden területen felülmúlja az ember szellemi képességeit (5. ábra) [13].

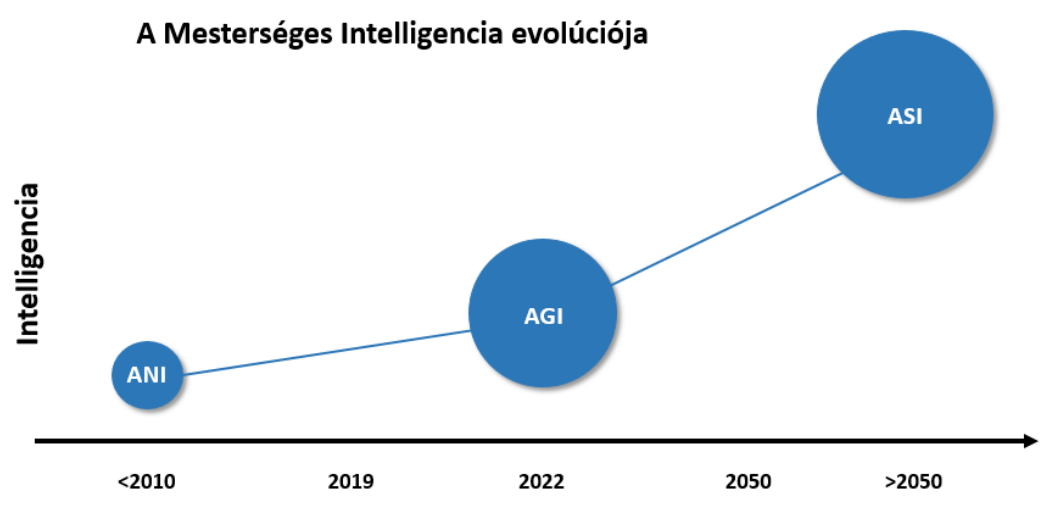

5. ábra A mesterséges intelligencia képességeinek várható fejlődése [14]

A 6. ábrából kiderül, hogy a ma ismert ANI, bár a piaci penetrációja még csak 4\%, mégis most ér a csalódottság fázisába. Ez alapján akár megtorpanás is várható mindaddig, amíg a felhasználók (főleg vállalatok) meg nem találják, hogy pontosan hogyan is teheti hatékonyabbá müködésüket a mesterséges intelligencia. A Gartner nemzetközileg elismert kutatócég legfrissebb (2018) elemzéseiből kiderül, hogy a Deep Learning szélesebb körben történő elterjedéséhez még legalább 2-5 évre van szükség. A tanulmányból az is kiderül, hogy az elkövetkező 10 évet is a MI technológiák fogják uralni [15].

Szintén a Gartner kutatói szerint a közeljövő legnagyobb fejlődése az AGI, tehát általános - emberhez hasonló - intelligenciával rendelkező MI megjelenése. Érdekesség, hogy a teljes mértékben önvezető - akár ember szállítására is alkalmas - légijármüvek ${ }^{7}$ integrálása számos esetben egy könnyebben megoldható kihívás, mint a valóban (akár kormány nélküli) önvezető autó, mert a közútnál sokkal kontrolláltabb a közeg, kevesebb a változó és könnyebban függetlenné lehet tenni az embertől. Természetesen ez óriási szabályozási és társadalmi kihívásokat jelent a jövőben (hova telepíthetünk helikopter fel- és leszállóhelyeket, hogy kerüljük el az ütközéseket). Mégis, a Gartner már 2018 egyik legfejlődőbb techológiái közé sorolja a repülő önvezető jármüveket [14] [16].

${ }^{7}$ Urban Air Mobility - Városi légi mobilitás 


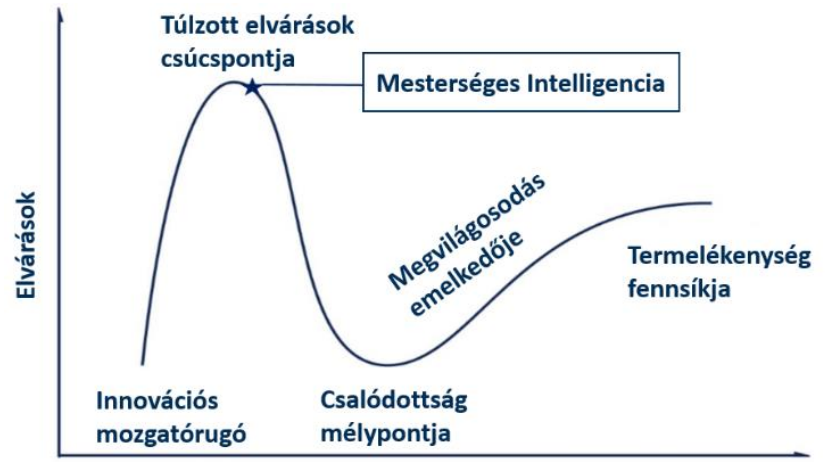

6. ábra A mesterséges intelligencia a Gartner Hype Cycle ábráján [15]

\section{AVIATIKAI ALKALMAZÁSOK}

A MI alkalmazása az elmúlt 15 évben a repülésben is gyors fejlődésnek indult. Ennek alapvetően, a bemutatott trendeken túl, az óvatos becslések mellett is 2037-re megduplázódó légiforgalom okozta kihívások a fö mozgatórugói [17]. A következőkben bemutatott példákon keresztül, fókuszba állítva az európai légiközlekedést, ezen fejlődés eredményeit, kutatási irányait és jövőbeni alkalmazási lehetőségeit foglaljuk össze.

Az európai kutatások túlnyomó része a $\mathrm{SESAR}^{8} \mathrm{JU}^{9}$ szárnyai alatt valósul meg, amely összefogja az európai légiközlekedési szereplők kutatási és innovációs tevékenységeit, valamint EU források biztosítása útján segíti azok megvalósulását. A SESAR projektek két fó általános célja a repülési teljesítménymutatók javítása és a légiforgalmi irányítás $\left(\mathrm{ATM}^{10}\right)$ modernizálása a legújabb technológiák és egy nagyfokú digitalizálás bevezetésével. A négy ilyen repülési $\mathrm{KPA}^{11}$ a biztonság, a hatékonyság, a kapacitás és a környezeti hatások [18]. A mesterséges intelligenciát használó új megoldások és alkalmazott kutatási irányok is ezek javítására irányulnak.

\section{Forgalmi elörejelzéssel kapcsolatos alkalmazások}

A mesterséges intelligencia egyik nagy területe, a gépi tanulás a repülésben is lehetővé teszi olyan elörejelzések készítését, amit korábban analitikus módon nem lehetett volna felállítani. A gépi tanuló algoritmusokat a repülésben vagy légiforgalmi irányításban nap, mint nap keletkező hatalmas mennyiségü adaton alkalmazva olyan összefüggések is láthatóvá válnak, amik korábban azok összetettsége miatt nem voltak sejthetők, vagy, ha sejthetök is voltak, pontos elörejelzéseket az összefüggések matematikai leírása nélkül nem lehetett tenni.

A forgalom előrejelezhetőségének a fontossága az európai légtérben különösen kritikus, hiszen az ellenőrzött légtérben az egyes szektorok kapacitása és a bennük jelentkező repülési igények már a mostani forgalom mellett sincsenek gyakran egyensúlyban és a kapacitást meghaladó igények késéseket eredményeznek. A jelenlegi, egyes területeken súlyosnak mondható kapaci-

\footnotetext{
${ }^{8}$ SESAR - Single European Sky ATM Research - Egységes Európai Égbolt technológiai pillére

${ }^{9}$ SESAR JU - SESAR Joint Undertaking - SESEAR és nem tag szervezetek közös vállalkozása

${ }^{10}$ ATM - Air Traffic Management - Légiforgalmi irányítás

${ }^{11} \mathrm{KPA}$ - Key Performance Areas - Kulcs teljesítménymutató területek
} 
tásproblémák rövid távú megoldása nem valószínü, ráadásul minden szereplö forgalomnövekedéssel számol, ezért a megfelelő forgalomszervezés $\left(\mathrm{ATFCM}^{12}\right)$ kulcsfontosságú feladat. E tevékenység célja, hogy az egyes szektorokban, illetve reptereken lévő irányítási kapacitás és a repülési igények közötti egyensúlyt biztosítsa, vagy, ha az igények túllépik a kapacitásokat, a forgalomáramlást úgy optimalizálja (például résidők osztásával az induló repülőtéren), hogy a járatok által érintett egyik szektorban se lépje túl a forgalom az adott szektor kapacitását. A feladathoz az egyes szektorok kapacitásait és a repülési igényeket (vagyis a repülési terveket) kell ismerni. Az európai légiforgalom áramlásszervezését végző EUROCONTROL NMOC ${ }^{13}$ egysége négy tervezési fázisra osztja tevékenységét [19]:

$\downarrow$ stratégiai tervezés (több mint 7 nappal az üzemelés előtt): Ebben a fázisban az egyes ANSP $^{14}$-k számára elörejelzik a várható igényeket, amelyhez számításba veszik az elérhető útvonalakat, illetve az esetleges egyéb légtérhasználatot is (katonai tevékenységek, korlátozott légterek ...);

$\dashv$ pre-taktikai tervezés: (1 - 6 nappal az üzemelés előtt): A stratégiai tervezés finomhangolásával napi terveket készítenek, amelyek kimenete az Európai Légtérhasználati Terv $\left(E A U P^{15}\right)$ és frissítései $\left(E U U P^{16}\right)$ benne az aktuálisan használható és nem használható légterekkel és útvonalakkal;

$\neg$ taktikai tervezés (az üzemelés napján): A NMOC valós időben értékeli a napi terveket, és beavatkozik szükség szerint (például különleges időjárási helyzet, földi vagy légtérbeli elemek kiesése, pontosított repülési tervek miatt);

$\neg$ üzemelés utáni elemzések: ezek a tevékenységek a historikus adatokat felhasználva segítenek a jövőbeni tervezések finomításában.

Látható tehát, hogy az áramlásszervezi tevékenységek támogatására a forgalmi elörejelzéseknek a repülés minden fázisában szerepe van és minél pontosabb egy ilyen elörejelzés, annál eredményesebb intézkedéseket tehet az áramlásszervező a forgalom zavartalan biztosítására. A pontos előrejelzéseket pedig az olyan gépi tanuló algoritmusok szolgáltatják, amelyek nagyon sok adat vizsgálatával függvénykapcsolatot hoznak létre az input adatok és az elörejelezni kívánt tényezők között.

\section{Trajektória elörejelzési lehetőségek}

Az egyik legtöbbet és legrégebben kutatott terület a témában a taktikai szintű tervezéshez kapcsolódik, vagyis a repülésnek ahhoz a fázisához, amikor a repülőgép már a levegőben van. A felderítési infrastruktúra elemei által szolgáltatott nagy mennyiségü adatok visszamenőleges elemzéséből, a lerepült trajektóriák jellemzőiből a gépi tanuló algoritmusok által felépített modellek számos időbeli előrejelzést tudnak készíteni a repülőgép mozgásjellemzőit illetően. Ezek segítségével az egyes szektorok kapacitásproblémái már korai fázisban felismerhetők és kezelésük is egyszerübb. A másik felhasználása ezen előrejelzéseknek pedig az ATM rendszerek alapvető eszköztárához kapcsolódik, ami nélkül a mai légiforgalmi irányítás már nem is képzelhető el hatékony módon. A légiforgalmi irányítók számos hasznos elörejelző funkciót használhatnak a radarernyőn, amelyek müködésének alapjai szintén a trajektória-előrejelzéseken nyugszanak.

\footnotetext{
${ }^{12}$ ATFCM - Air Traffic Flow and Capacity Management - Légiforgalmi áramlásszervezés

${ }^{13}$ NMOC - Network Management Operation Centre - Network Management Mủveleti Központ

${ }^{14}$ ANSP - Air Navigation Service Provider - Légiforgalmi Szolgálat

${ }^{15}$ EAUP - European Airspace Use Plan - Európai Légtérhasználati Terv

${ }^{16}$ EUUP - European Updated Airspace Use Plan - Frissített Európai Légtérhasználati Terv
} 
A gépi tanulásnak azért van létjogosultsága ezen a területen, mert az egyszerüen és explicit módon számítható, egyenletekkel leírható dinamikai modellekhez - amelyek a legpontosabb képet adnák a repülőgép mozgásállapotának előrejelzéséhez - nem áll rendelkezésre elegendő és elég pontos adat a földi számításokhoz. A legtöbb hagyományos trajektória elörejelzés által használt tömegpont modell (ahol a repülögép egy kiterjedés nélküli tömeggel rendelkező pontnak tekinthető, amelyre erők hatnak) ugyanis számos mozgásegyenlet útján kiszámítja a repülőgép pozícióját egy megadott időpontban, de ehhez ismerni kell a kezdeti mozgásjellemzőket (tömeg, tolóerő, pozíció, sebesség), a légköri állapotokat (szél, hőmérséklet) és a repülőgép megkívánt müködtetési jellemzőit (sebesség és gyorsulás profil, cost-index, hajtómü-beállítások). Nem arról van szó tehát, hogy Newton klaszszikus mechanikai törvényeivel ne lehetne pontos előrejelzéseket tenni egy repülögép mozgásáról (emelkedéséről, gyorsulásáról, a repülési trajektória időbeli lefolyásáról), hanem arról, hogy az ehhez szükséges adatoknak csak nagyon korlátozott száma (leggyakrabban: sebesség, magasság, földrajzi pozíció) áll rendelkezésre a földön a számításokhoz. Nem ismerjük például az aktuális szelet, a repülőgép üzemeltetésének jellemzőit, a hajtóművek müködési állapotait, a légijármü tömegét, hogy csak néhányat említsünk a hiányzó tényezők közül. Természetesen a fedélzeten ezek rendelkezésre állnak, és a robotpilóta is ebböl számítja ki a szükséges manővereket, de a földön a nagy részük nem elérhető, vagy nem elég pontos. A repülőgép tömege, a hajtómübeállítások, a sebességprofilok például érzékeny adatok az üzemeltetők részéröl és nem kerülnek lesugárzásra a földi egységekhez, a radaradatok és időjárás információk nem pontosak. Nem állítjuk, hogy ez az állapot nem változik meg a közeljövőben, de addig is, a múltbeli adatokból „betanított” mesterséges intelligencia reális alternatívát jelent megbízható előrejelzések készítéséhez. Annál is inkább, mert még ha rendelkezésünkre állnának is a legpontosabb adatok a számítások elvégzéséhez, nem hagyhatjuk figyelmen kívül azt a tényt sem, hogy egy sztochasztikus folyamatot nem tudunk hiba nélkül determinisztikus megközelítésben vizsgálni. A repülési trajektória ugyanis folyamatosan véletlenszerü behatásoknak van kitéve, így sztochasztikus problémáról beszélhetünk. A mesterséges intelligencia (big data elemzések, gépi tanulási algoritmusok) pont az ilyen helyzetekre kínál megoldást, mert csupán az adatokban fellelhető mintákra összpontosít, ezáltal figyelembe tud venni olyan tényezöket is egy adott rendszer müködését illetően, amelyek létéről lehetséges, hogy nincs is tudomásunk.

A trajektória előrejelzések fejlesztésének középpontjában a vertikális profil minél pontosabb meghatározása játssza a kulcsszerepet, hiszen horizontálisan a mai navigációs technológiák mellett a repülőgépek nagy pontossággal le tudják követni az útvonalukat. Légijármüvek repülésének vertikális profilját már 1999-ben sikerült neurális hálók segítségével előrejelezni. Allioit és Fablec munkájukban alátámasztották, hogy a neuronháló alapú paraméterezett modellezés pontosabb előrejelzésekre volt képes, mint az addig általánosan használt nem parametrikus, repülőgéptípus jellemzőket felhasználó modellek. Munkájuk azért is figyelemre méltó, mert csupán két bemenő változó felhasználásával dolgoztak: a repülögép típusával és a kért repülési szinttel ( $\left.\mathrm{RFL}^{17}\right)$. A historikus adatok alapján betanított modelljük képes elörejelezni géptípusonként a vertikális repülési profilt repülés közben (a már lerepült trajektória adatait felhasználva) és repülés elött is [20].

A Toulouse-i ENAC ${ }^{18}$ kutatói 2013-ban különbözö regressziós módszerekkel kaptak hasonlóan biztató eredményeket az adat alapú trajektória előrejelzéseket illetően. Ellentétben a korábbi próbálkozással, itt már 76 különböző input változót vettek számításba az előrejelzések leírására.

\footnotetext{
${ }^{17}$ RFL - Requested Flight Level - Kérelmezett reülési szint

${ }^{18}$ ENAC - École Nationale de l'Aviation Civile
} 
Az eredmények jól mutatják, hogy ilyen nagyszámú változó figyelembevétele esetén miért célszerü megoldás a gépi tanuló algoritmusokat segítségül hívni egy ilyen összetettségü probléma megoldásához [21].

Hasonlóan jó eredményeket hozott több elmúlt évekbeli kutatás és doktori értekezés is, amelyek szintén különböző gépi tanulási modelleket felhasználva készítettek trajektória elörejelzéseket [22] [23] [24]. Mindegyikben az a közös, hogy a fizikai modellt elrejtve, mintegy ,fekete dobozként" tekint a trajektóriát meghatározó összetevőkre és az előrejelzést egy lépésben, közvetlenül a repülőgép múltbeli pozícióinak lefolyásából készíti el. Ezzel szemben Alligier és társainak legújabb megközelítésében (7. ábra) a fizikai modell számítja ki a jósolt pozíció adatokat, a mesterséges intelligencia csupán az ehhez szükséges inputokat szolgáltatja, vagyis azokat az ismeretlen változókat, amelyek elengedhetetlenek a fizikai modell számára [25] [26]. Kutatásukban múltbeli minták felhasználásával felépített modelljük 9 repülőgéptípus esetében „jósolja” a tömeg és sebességprofil adatokat a már lerepült trajektória alapján és ezek rendelkezésre állásával már számíthatják klasszikus fizikai modell szerint a várható trajektóriát 10 percre elöre. Érdekesség, hogy az így kapott előrejelzés sebesség- és magassághibája minimum $36 \%$-kal volt alacsonyabb, mint a modellezésekhez általánosan használt BADA ${ }^{19}$ repülőgép adatbázis referencia tömeg és sebesség adataiból számított előrejelzés esetén.

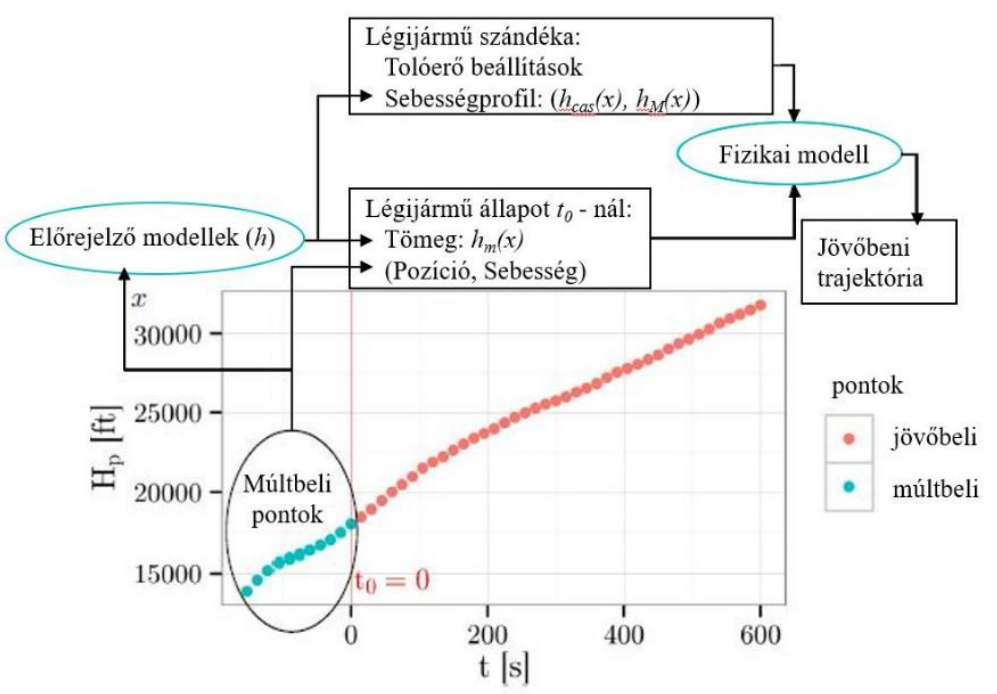

7. ábra Vertikális profil előrejelzési modell megvalósítási lehetősége [26]

A téma fontosságát az is mutatja, hogy SESAR projekt keretében is indult egy nagyméretü kutatás DART ${ }^{20}$ néven felhasználva európai szinten a repülési adatbázist. A kutatás célja öszszetett és két részből áll: egyedi trajektória előrejelzés készítése gépi tanulási algoritmusok segítségével (Rejtett Markov Modell, $\mathrm{SVM}^{21}$, döntési fák...) és ezeket felhasználva ágensalapú modellezéssel az igény - kapacitás egyensúlyi problémák kezelése az egyes szektorokban. A cél, hogy az előrejelzés az áramlásszervezés pre-taktikai fázisában is már megbízhatóan elér-

\footnotetext{
${ }^{19}$ BADA - Base of Aircraft Data - Repülőgép adatbázis

${ }^{20}$ DART - Data-driven Aircraft Trajectory Prediction Research - Adatvezérelt légijármü-trajektória előrejelző kutatás

${ }^{21}$ SVM - Support Vector Machines - Szupport vektor gépek
} 
hető legyen. A projekt kedvező kimenetele esetén az ATM iparág elmozdulhatna egy trajektória-alapú működés felé, amelynek várható előnye, hogy a világszinten jelentkező óriási méretű repülési igények kezelhetők lesznek [27].

\section{ETA22 elörejelzés}

Az előzőekben bemutatott előrejelzések a megközelítés fázisában kevésbé alkalmazhatók. A $\mathrm{TMA}^{23}$-kban lévő repülések az esetek túlnyomó részében ugyanis vektorálás alatt vannak, vagyis a lerepült útvonal mind horizontális, mind vertikális síkban nagyon eltérő lehet az egyes repülések esetén. Éppen ezért más módszert kell alkalmazni a repülés ezen fázisában lévő előrejelzésekhez.

A témával részletesen foglalkozott többek között egy francia-kínai kutatás (Wang et. al, 2017), amelynek eredményeképpen a pekingi TMA-ba berepülő légijárművek várható érkezési idejét lehet előrejelezni. A Beijing Capital International Airport (BCIA) a világ egyik legforgalmasabb repülőtere három futópályával, ahol egy pontos előrejelző modell nagyban tudja könnyíteni a repülőtéri irányítási műveleteket. A modell megalkotása két lépésben történt, mindkettőhöz a mesterséges intelligencia módszereit használták fel. Első körben a nagyszámú valós repülési trajektóriát tartalmazó tanító adatbázisból jól elkülöníthető csoportokba (klaszterekbe) sorolták a hasonló jellegzetességgel bíró útvonalakat (8. ábra).

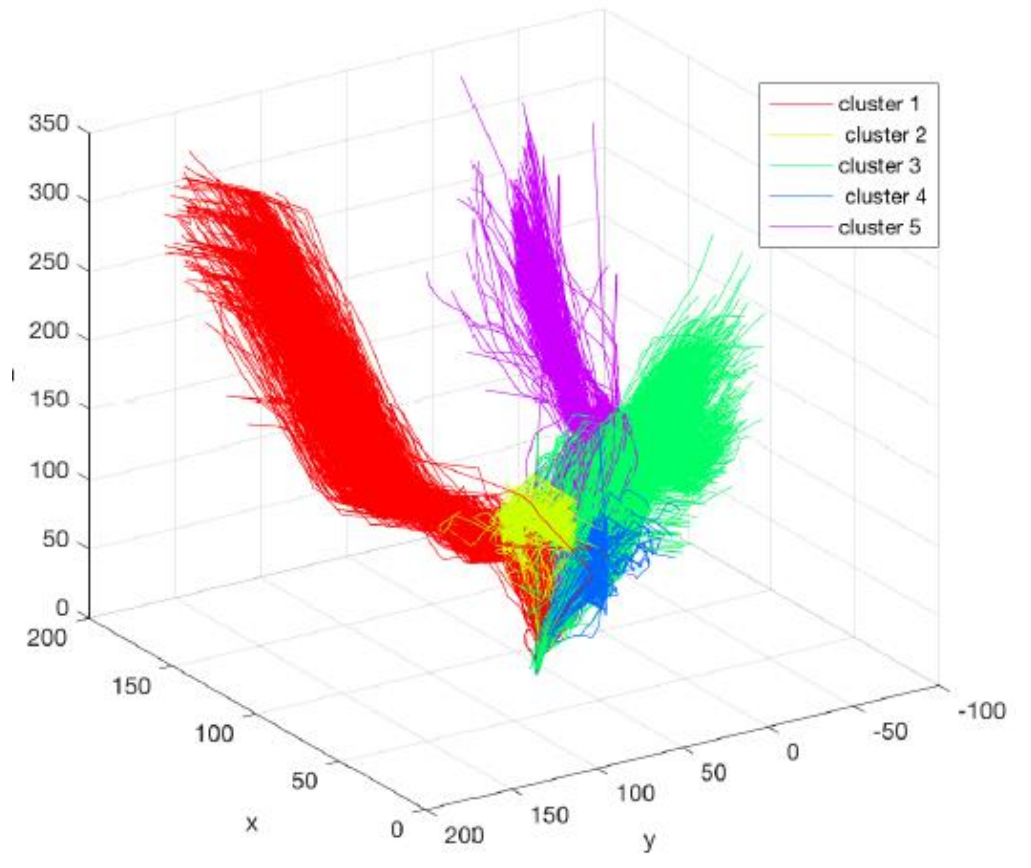

8. ábra Megközelítési trajektóriák csoportosítása klaszterezési eljárással [28]

Ezután mesterséges neurális hálózatokkal tanították be a modellt arra, hogy minden egyes klaszter esetében megjósolja a repülőgép földet érési idejét. Ehhez a hálózatot sokféle bemenő változóval kell ellátni, úgymint a repülőgép három koordinátája, a távolsága a földet érési ponttól és az alapfalra fordulás pontjától, a heading, a sebesség $\left(\operatorname{IAS}^{24}\right)$ vagy a vertikális sebesség. A betanítás után a rendszer képessé vált arra, hogy egy új érkező légijármű esetén a fenti bemenő adatok ismeretében először a megfelelő klaszterbe sorolja a trajektóriát, majd előrejelezze a várható érkezési

\footnotetext{
${ }^{22}$ ETA - Estimated Time of Arrival - Várható érkezési idő

${ }^{23}$ TMA - Terminal Control Area - Közelkörzeti irányítói körzet

${ }^{24}$ IAS - Indicated air speed - Müszer szerinti sebesség
} 
időt az adott klaszter modellje alapján. A tapasztalatok azt mutatták, hogy a modell már fél órával a földet érés előtt 150 másodperces átlagos pontossággal képes meghatározni a repülőgép érkezését, ami 10 perccel a földet érés elött már 50 másodperc alatti pontosságra csökken [28].

\section{Légitársaságok útvonalválasztása}

Míg a taktikai fázisban lévő repülések trajektória előrejelzéseire és időbeni lefolyására számos modell készült és több helyen alkalmazzák is azokat, a pre-taktikai és stratégiai tervezés támogatására eddig csak kevéssé fókuszáltak. A SESAR JU INTUIT ${ }^{25}$ kutatási programjának keretében azonban spanyol kutatók logisztikus regresszió és döntési fa modelleket alkalmazva biztató eredményeket kaptak azt illetően, hogyan lehet még a repülési tervek benyújtása előtti fázisban megjósolni egy adott desztináció-pár közötti repülési útvonalat. Mint ismeretes, két város között számos útvonalon lehet repülni, a légitársaságok választása pedig akár repülésenként változhat. Az NMOC eddigi előrejelzési gyakorlata olyan útvonalakat feltételez, mint a korábbi hetek hasonló repülési tervében szereplők, ez a hasonlósági feltételezés azonban nem vesz számításba számos más befolyásoló tényezőt, így nem is ad megbízható előrejelzéseket. Az INTUIT program kutatói, 3 desztináció-pár példáján tesztelték modelljüket, ahol historikus adatok alapján a desztániációk közötti repült útvonalakat hasonlósági alapon klaszterekbe sorolták (9. ábra).
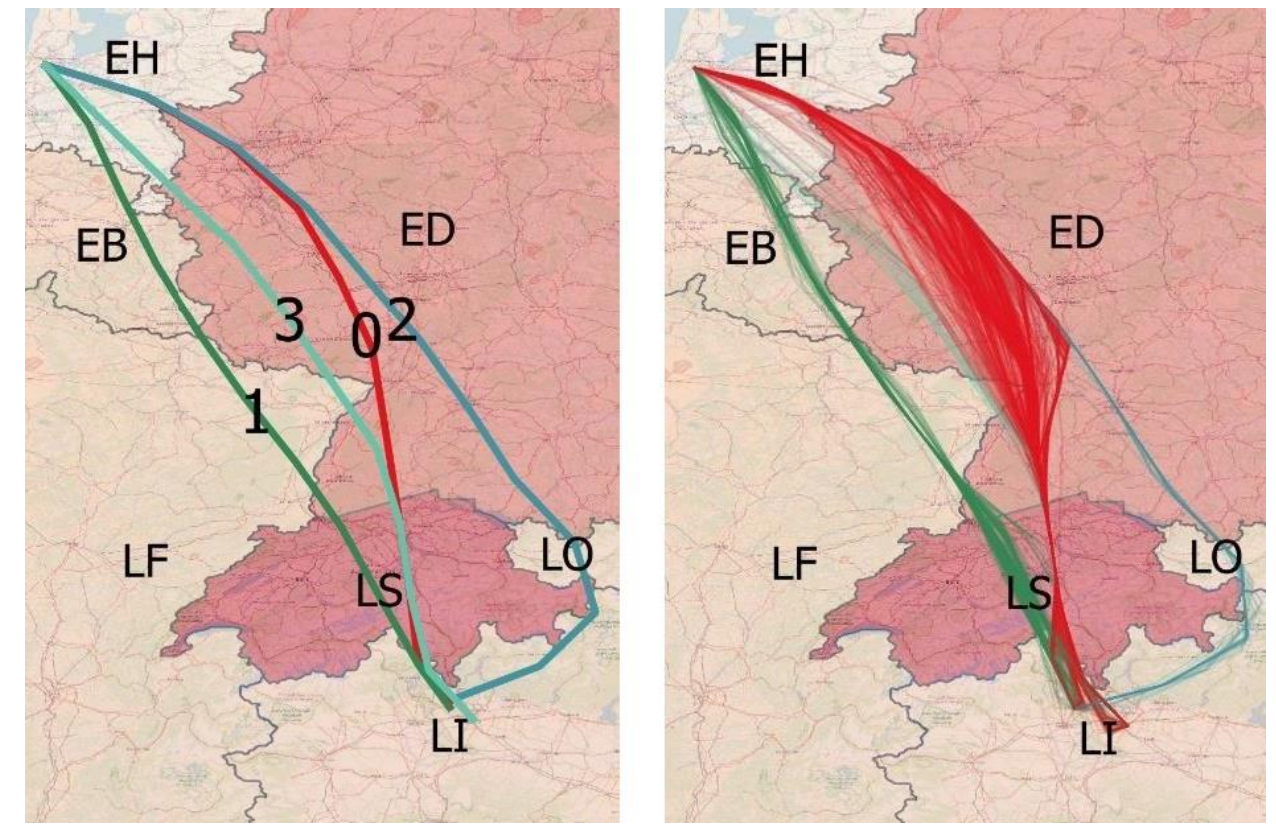

9. ábra Amszterdam - Milánó közötti repülési útvonalak csoportosítása [29]

Az egyes klaszterek más-más jellemzőkkel bíró útvonalakat valósítanak meg. Ezen jellemzők közül a kutatásban a repülési távolság, a navigációs díjak (eltérőek az egyes országokban) és az adott útvonal zsúfoltságát jellemző arányszám szerepeltek. A tanítási adathalmaz repülései pedig szegmentálva voltak légitársaságonként (valójában a repülés egy ülésre jutó költségei szerint, ami légitársaságonként egy időszakban azonos) és a repülés időszaka szerint (reggeli vagy délutáni csúcs, illetve ezek között). A kutatás célja az volt, hogy adott tulajdonságú repülés esetére (egy ülésre jutó költség és napszak), adott jellemzőkkel bíró útvonalcsoportok (klaszterek) mellett elörejelezhető legyen, hogy a járat melyik klaszter szerinti útvonalon fog repülni,

\footnotetext{
${ }^{25}$ INTUIT - Interactive Toolset for Understanding Trade-offs in ATM Performance - Légiforgalmi irányításban fellelhető „,trade-off” helyzetek feltárását célzó interakív eszköztár.
} 
illetve melyiken milyen valószínüséggel. A historikus adatokkal betanított és megfelelően paraméterezett modell segítségével ezután megadható, hogy egy adott viszonylaton milyen arányban oszlanak el a különböző útvonalak között az oda üzemelő repülések. Ez pontosabb elörejelzést ad, mint az eddig alkalmazott eljárás, eredményeképpen, ha minden desztináció-párra alkalmazzák, jól lokalizálhatók már a stratégiai tervezés szintjén is a hotspotok, illetve a várhatóan zsúfolt szektorok. A kutatás felhívja a figyelmet arra, hogy a modell, bár így is használható, további finomításokkal (pl.: szél, időjárás figyelembe vétele) tovább pontosítható. Összességében elmondható, hogy a gépi tanulás sikeresen le tudja modellezni az olyan összetett szempontrendszerü döntéseket is, mint amilyen a légitársaságok útvonalválasztása és ez a stratégiai szintű áramlásszervezésben az előrejelzéseket jelentősen pontosíthatja [29] [30].

\section{Légiforgalmi irányítással kapcsolatos további alkalmazások}

Az előzőkben bemutatásra kerültek a forgalom lefolyásával kapcsolatos legtöbbet kutatott területek, ahol mesterséges intelligencia segítségével teszik előrejelezhetővé a sokszor sztochasztikus folyamatokat. Ezek elengedhetetlen részei ma már a légiforgalmi irányításnak. A következőkben bemutatott alkalmazások túlnyomórészt az ATM rendszerek támogatását szolgálják és jó példák arra, milyen extra lehetőségeket tudnak nyújtani a legújabb MI alapú modellek.

\section{Dinamikus légtérkonfiguráció}

A légiforgalmi irányitásban a szektorizáció kialakítása az aktuális forgalomnagyság függvényében manapság jórészt intuitív, az ANSP-k áramlásszervező szolgálatának $\left(\mathrm{FMU}^{26}\right)$ adatai szerint kerül meghatározásra. Az FMU-k Európában a központi áramlásszervezőtől, az EUROCONTROL-tól kapják a forgalmi előrejelzéseket, ezek alapján döntenek az irányítói munkateremben az aktuálisan működő szektorok számáról és összetételéről. Alacsonyabb forgalom esetén szektorokat vonhatnak össze, míg nagyobb vagy komplexebb forgalom esetén kisebb egységekre bonthatják az adott szektort. Ezek a szektornyitások és -zárások időben dinamikusan, az adott forgalmi helyzetnek megfelelően, de emberi döntéssel valósulnak meg, ahol a döntés alapja általában a várható forgalomnagyság és az adott szektor kapacitásának viszonya. A gyakorlat azonban azt mutatja, hogy az irányítói munkaterhelés nem csak a forgalomnagyságtól függ, hanem annak komplexitásából adódóan számos más tényezőtől is, amelyeket nem ismerünk. Ennek értelmében egy adott szektorizáció nem szükségszerűen eredményez ideális munkaterhelést a légiforgalmi irányítóknak, sokszor meghaladja a biztonságos szintet. A probléma kellő motivációt jelent ahhoz, hogy MI alkalmazásával megpróbálják előrejelezni az ideális munkaterhelésnek megfelelő szektor konfigurációt.

A probléma nehézségét az is fokozza, hogy magát a munkaterhelést is nehéz objektív módon mérni és arról is többféle tanulmány született, hogy ennek mi a megfelelő módja. Egyesek a fizikai aktivitást [31], mások a fiziológiai jellemzőket [32] [33], megint mások szubjektív irányítói értékelési eljárások eredményeit vennék alapul [34]. Ezek mellett az sem egyértelmü, hogy melyek azok a tényezők, amelyek hozzájárulnak a munkaterheléshez, vagyis mik lehetnek az input adatai az elörejelző modelleknek. Ebből a szempontból is érdekesek David Gianazza kutatásai, aki már az input változók meghatározására és ok-okozati kapcsolatok igazolására is gépi tanulási technikákat alkal-

${ }^{26}$ FMU - Flow Management Unit - Áramlásszervező egység 
mazott. Modelljében a munkaterhelési szinteket három kategóriába sorolta, ezzel a problémát klaszterezési feladatként kezelte. Alacsony terhelésűnek tekintett egy szektort akkor, ha azt összevonták egy másikkal, magas terhelésünek, ha szétbontották és normál terhelésünek minden más esetben. A munkaterhelést leíró, kezdetben 27 darab input változót főkomponens analízissel 6-ra redukálta és kutatásában igazolta, hogy ebből 5 valóban egyértelműen magyarázza a munkaterhelés alakulását és nem csak intuitív a kapcsolat. Ez a hat tényezö a következő:

$\rightarrow$ az adott szektor mérete;

$\rightarrow$ a légijármüvek száma az adott szektorban;

$\downarrow$ bejövő forgalom a következö 15 percben;

$\uparrow$ bejövő forgalom a következő 60 percben;

$\downarrow$ az átlagos függőleges sebessége a légijármüveknek az adott szektorban (ennél a jellemzőnél nem egyértelműen bizonyított a kapcsolat);

† a 20 foknál nagyobb szögben találkozó sebességvektorok száma.

Gianazza ezután több különböző módszer ( $\mathrm{LDA}^{27}, \mathrm{QDA}^{28}$, Naive-Bayes, neurális hálózatok és $\mathrm{GBM}^{29}$ ) alkalmazásával betanította modelljét az elörejelzésre, ami a legjobb módszer esetében 82\%-os pontossággal müködött is abban a légtérben, ami a tanuló adatbázist is szolgáltatta. További kutatásaiban rámutatott, hogy modellje továbbfejlesztésre szorul, más légterekben nem hozza a kívánt pontosságot és a három kategóriába sorolt munkaterhelési skáláján is lehetne finomítani. Mindezek ellenére jó példát szolgáltat arra, hogy mennyiféleképpen lehet alkalmazni a mesterséges intelligenciát ugyanarra a feladatra [35] [36].

A problémára lehet kevésbé összetett módon is tekinteni, és csupán azt vizsgálni, hogy mikor melyik szektorkonfigurációt érdemes alkalmazni annak érdekében, hogy a műveletszám ne haladja meg a szektorkapacitást. Ebben a felfogásban a probléma egy összetettebb kombinatorikai feladatra vezethető vissza, amit döntési fa algoritmussal vagy genetikus algoritmussal lehet hatékonyan megoldani. Ilyen megközelítésben vizsgálta a témát Gianazza mellett [37] az az ENAC kutatócsoport (Sergeeva et. al, 2017) is, akik genetikus algoritmust alkalmazva dolgoztak ki eljárást a dinamikus légtérkonfiguráció megoldására. Modelljükben a lehető legkevesebb nyitott szektor mellett kívánták a munkaterhelést elfogadható szinten tartani, nem foglalkozva azzal, hogy milyen tényezők okozzák azt. Genetikus algoritmusuk az összes lehetséges légtérkonfigurációt vizsgálva határozza a meg a legkedvezőbbet. Munkájuk jelentős gráfelméleti ismeretet tartalmaz és a maastrichti ACC légtérben müködőképesnek is bizonyult [38].

\section{Automatikus hangfelismerés alkalmazási lehetőségek}

Az utóbbi években az ATM iparágban is elkezdtek terjedni a hangfelismerést $\left(\mathrm{ASR}^{30}\right)$ használó alkalmazások és egyre több helyen képesek támogatni a légiforgalmi irányítók munkáját a munkaterhelésük csökkentésével. Mivel a hangfelismerés technológiája is gépi tanulásra épül, ezért fontosnak tarjuk bemutatni, hogy milyen lehetőségek rejlenek az alkalmazásában. Amíg az Apple-nek a Siri ${ }^{\circledR}$ vagy a Google-nek a Voice Search ${ }^{\circledR}$ megoldása több ezer órányi tanító hanganyag segítségével került kifejlesztésre, addig a légiforgalmi irányításban használt fónia jelentősen kötött szókincse miatt az itteni hangfelismerő alkalmazások betanításához pár 10

\footnotetext{
${ }^{27}$ LDA - Linear Discriminant Analysis - Lineáris diszkrimináns analízis

${ }^{28}$ QDA - Quadratic Discriminant Alaysis - Négyzetes diszkrimináns analízis

${ }^{29}$ GBM - Gradient Boosting Machines - Gradiens módszer gyorsító eljárás

${ }^{30}$ ASR - Automatic Speech Recognition - Automatikus hangfelismerés
} 
órányi hangadat is elegendő. Ráadásul, mivel a szórend is kötött és ugyanazt az utasítást csak kisszámú variációban lehet mondani, a tanítási folyamatot ez nagyban megkönnyíti [39].

Az alkalmazások tekintetében úttörőnek számít az AcListant ${ }^{\circledR}$ (Active Listening Assistant, 2013-2015) projekt, a német ANSP, a DFS, és a DLR (Deutsches Zentrum für Luft- und Raumfahrt) légiforgalmi irányító támogató eszköze. A támogatás alapú hangfelismerőben $\left(\mathrm{ABSR}^{31}\right)$ testet öltő irányítói eszköz 95\%-os pontossággal képes értelmezni az irányítói utasításokat és ennek megfelelően a radarképernyőn lévő címkék információtartalmát ellenőrizni (10. ábra). A továbbfejlesztett AcListant-Strips ${ }^{\circledR}$ megoldás pedig jelentősen képes csökkenteni az irányítói munkaterhelést azáltal, hogy az elektronikus címkék manuális (egér és billentyüzet alapú) frissítését a kiadott utasítást megértve automatikusan végzi el. A rendszeresen és nagy mennyiségben ismétlődő utasításokra Düsseldorf közelkörzeti légterében tesztelt alkalmazás óránként kettővel több légijármű leszállítását teszi lehetővé a 23R futópályára [40].

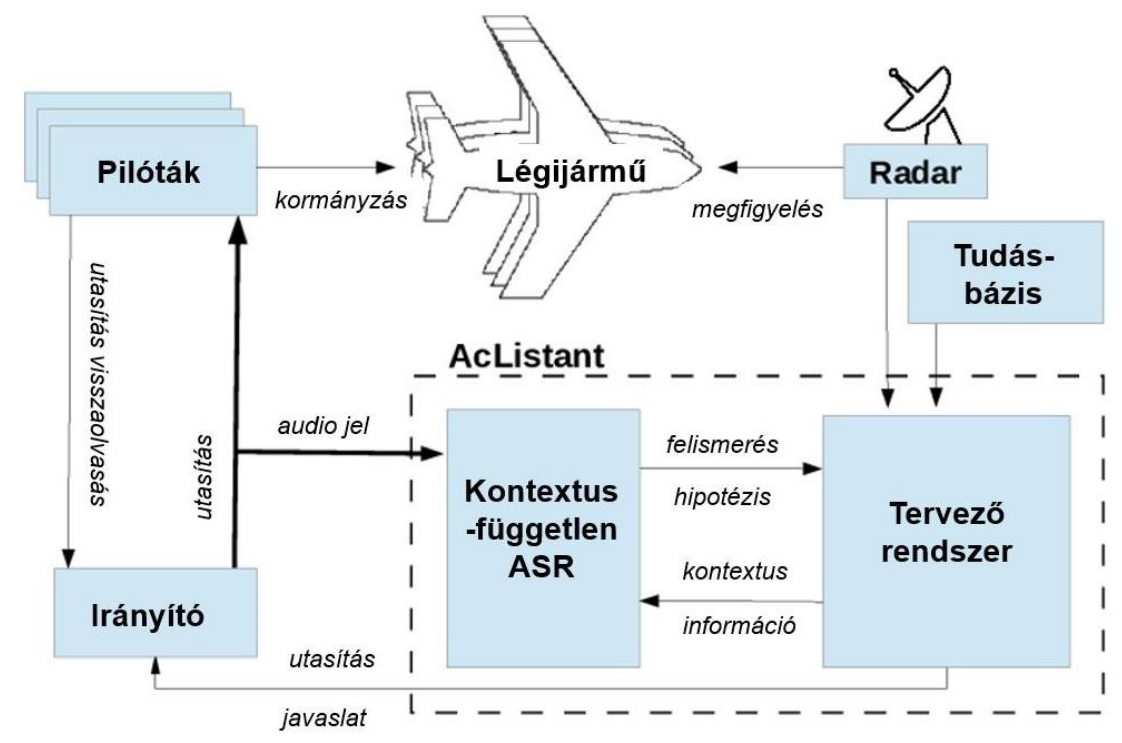

10. ábra Támogatás-alapú hangfelismerő rendszer sematikus müködési elve [41]

A SESAR keretek között megvalósuló MALORCA projekt a meglévő ABSR rendszerek továbbfejlesztését és önálló termékké alakítását tűzte ki céljául. A kutatásban gépi tanuló algoritmusokat segítségül hívva arra dolgoztak ki megoldást a szakemberek, hogyan lehet olcsón és könnyen adoptálni a meglévő eszközöket teljesen új környezetbe (más légtér, más akcentus, más irányítói eljárások...). A kutatás része volt az is, hogy a meglévő rendszerek irányítói utasítás felismerési hibáját további gépi tanításokkal tovább csökkentsék. Az eredmények tekintetében a prágai közelkörzeti légtérben 7,9\%-ról 0,6\% alá, míg a bécsi közelkörzeti környezetben 18,9\%-ról 3,2\%-ra sikerült csökkenteniük a felismerési hibarátát [42].

Az alkalmazási lehetőségek széleskörü felhasználhatóságát mutatja, hogy a további tervek között szerepel még az álpilóták munkájának kiváltása a hangfelismerés által. Ezt a légiforgalmi szimulációk során lehetne alkalmazni, ahol egy programozott pilótalogika a felismert irányítói utasítást szöveggé alakítva (speech-to-text) a szimulátornak kiadja a megfelelő parancsokat, illetve az utasításra válaszol (text-to-speech) az irányítónak. Ebben a szegmensben ért el biztató kutatási ered-

${ }^{31}$ ABSR - Assistant-based Speech Recognizer - Támogatás alapú hangfelismerő 
ményeket a HungaroControl Magyar Légiforgalmi Szolgálat Virtual Pseudo Pilot (VPP) projektje, ahol sikeresen alkalmaznak ASR rendszert a pilótalogika input adatainak generálására. Ez különböző akcentusokra is optimalizálva lett kialakítva. Kifejlesztésre került az irányítói utasításokra adott automatikus válasz generálása (a pilótalogika) is, jelenleg pedig a szimulátorral és a kommunikációs rendszerrel való összeköttetésen dolgoznak a magyar szakemberek.

\section{A toronyirányítás támogatása}

Az intelligens megoldások a toronyirányításban is megjelennek. A munka széleskörü támogatását teszik lehetővé a kameraalapú, képfelismerést használó rendszerek, komplex földi mozgások esetén a gurításokat támogató szoftveres megoldások, és a big data elemzések által betanított legkülönfélébb előrejelzések is. A teljesség igénye nélkül álljon itt néhány alkalmazási lehetőség.

Tavaly mutatta be kutatási eredményeit az a francia kutatócsoport, amely a repülőgépek végső megközelítési trajektóriáit elemezte és funkcionális fökomponens elemzés, valamint felügyelet nélküli gépi tanulási algoritmusok segítségével ki tudta szürni azokat az atipikus megközelítéseket és ezek jellemzőit, amelyek nem stabilizált megközelítésekhez vagy legrosszabb esetben földnek vezetett repülésekhez vezetnek $\left(\mathrm{CFIT}^{32}\right)$. A modell továbbfejlesztésével céljuk egy valós idejü alkalmazás kifejlesztése, amely a toronyirányításnak is támogatást tudna adni, jelezve azokat a megközelítéseket, amelyekből nagy eséllyel átstartolás lehet [43].

Különösen a távoli toronyirányítási rendszereknél nő meg a különböző kamerák szerepe, amelyek azon kívül, hogy a légiforgalmi irányítóknak az ,ablakot helyettesítik” még egyéb funkciókat is el tudnak látni. A MI által betanított objektumfelismerési funkcióval rendelkező kamerákat lehet úgy programozni, hogy adott repülögépet automatikusan kövessen, kényelmesebbé téve ezzel az irányítói munkát. Szintén az objektumdetektálást alkalmazva van szerepe az olyan kameraalapú jelzőrendszereknek is, amelyek a futópályákon lévő törmeléket, állatokat, jármüveket, vagy egyéb nem odaillő tárgyakat (gyüjtőnevén: FOD ${ }^{33}$ ) azonosítanak. A FOD automatikus és gyors detektálása legfőképpen a nagyforgalmú repülőtereken kulcsfontosságú, hiszen azokon a sürü forgalom mellett kevés idő van a manuális pályaellenőrzésre. A problémát egészen az utóbbi évekig LIDAR ${ }^{34}$, vagy egyéb radar elven múködő detektorokkal oldották meg a legtöbben, azonban a kameratechnológiával egyidejüleg a mesterséges intelligencia alapú képfelismerés is fejlődött annyit, hogy nagyfelbontású kameraképeken előre betanított objektumokat felismerjen a rendszer. Ennek előnye az eddigi technológiával szemben az olcsósága lehet, illetve, míg a radaralapú érzékelőket sűrün kell telepíteni a futópályák mellé, addig a megfelelő felbontással rendelkező kamerákból kevesebb is elegendő. Infrakamerák alkalmazásával a sötétben is lehet látni, valamint vannak olyan megoldások is, amelyek a futópályák burkolatának állapotát és a vízzel vagy hóval való borítottságukat is elemezni tudja [44].

Több nagyobb forgalmú, vagy összetett gurulóúthálózattal rendelkező repülőtér esetében alkalmaznak valamilyen döntéstámogató szoftvert a gurító irányító megsegítésére. Ezek jó része a gurítóradart is tartalmazó modern A-SMGCS ${ }^{35}$ rendszerekben már integrálva érhető el, de létez-

\footnotetext{
${ }^{32}$ CFIT - Controlled Flight Into Terrain - Földnek vezetett repülés

${ }^{33}$ FOD - Foreign Object Debris - A futópályák, guruló utak és forgalmi előterek környezetében található hulladék

${ }^{34}$ LIDAR - Light Detection and Ranging - Lézer alapú távérzékelés

${ }^{35}$ Advanced Surface Movement Guidance and Control System - Földi mozgást felderítő és ellenőrző összetett rendszer
} 
nek különálló megoldások is. A szoftveres támogatás sok esetben evolúciós algoritmusokon alapszik, amely szintén a mesterséges intelligencia területei közé tartozik. Jó példa erre a német DLR által fejlesztett megoldás (TRACC ${ }^{36}$ ), ami konfliktusmentes gurulási útvonalakat biztosít a futópályák és az állóhelyek között. A program kétféle megközelítésben optimalizálja az útvonalakat: a repülőgépek útvonalának és a sebességének változtatásával. A rendszer számításba tudja venni a még levegőben lévő, illetve az állóhelyen álló repülőgépeket is. Az útvonalak tervezése során a késéseknek, az útvonal hosszának, valamint a megállások számának minimalizálására törekszik az alkalmazás. Az optimalizált megoldás megvalósításához az irányítónak javaslatokat ad a megfelelő utasításokra (11. ábra). Fontos kiemelni, hogy a hasonló rendszerek fontos részét képezhetik a repülőtéri szereplők integrált döntéstámogató platformjának $\left(\mathrm{A}-\mathrm{CDM}^{37}\right)$ is, amely alkalmazásával a repülőterek müködésének hatékonyságát jelentősen lehet növelni [45] [46].

\begin{tabular}{|c|c|c|c|c|}
\hline \multicolumn{3}{|c|}{ G) Commands } & & \multirow{2}{*}{$x$} \\
\hline 26 & LH5500 & Line up rwy 33. & $\Leftrightarrow$ & \\
\hline 5 & C91610 & Reduce speed to $13 \mathrm{kt}$. & & \\
\hline 3 & LH5500 & Increase speed to $10 \mathrm{kt}$. & & \\
\hline-30 & C91610 & Reduce speed to $16 \mathrm{kt}$. & & \\
\hline-30 & C91610 & Reduce speed to $26 \mathrm{kt}$. & & \\
\hline-30 & C91610 & Exit runway via taxiway $P$. & & \\
\hline-30 & C91610 & $\begin{array}{l}\text { Taxing via taxiways P, K, } \\
\text { I_South, G to position } 46 \text {. }\end{array}$ & & \\
\hline-99 & LH5500 & Increase speed to $8 \mathrm{kt}$. & 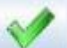 & \\
\hline & & & & - \\
\hline
\end{tabular}

11. ábra Utasítás-javaslatok a gurítóirányítónak egy gurulási útvonaloptimalizáló szoftverben [46]

\section{Egyéb kapcsolódó felhasználások}

A legfontosabb felhasználási területek bemutatása után néhány további gondolatébresztő alkalmazási lehetőségre hívnánk fel a figyelmet.

\section{A drónok és a mesterséges intelligencia}

Általában amikor az aviatikát és a mesterséges intelligenciát együtt említjük, a fö terület, ami nagy valószínűséggel elsőre eszünkbe jut azok a pilóta nélküli légijárművek más néven a drónok. A MI szerepe jelenleg is megkérdőjelezhetetlen a drónok világában, hisz fedélzeti alkalmazásként már ma is használatos és nélkülözhetetlen a biztonságos repülések érdekében. Gondoljunk csak az akadály- és ütközéselkerüléséhez szükséges képfelismerésre, elemzésre, vagy akár az objektumfelismerö és követő technológiákra.

A MI által irányított fedélzeti képességek mellet a drónok irányítását és menedzselését végző rendszer sem képzelhető el mesterséges intelligencia nélkül. Napjainkban egyre növekszik az igény a BVLOS ${ }^{38}$ repülésekre, elég csak a csomagkiszállításra, sürgősségi vér vagy defibrillátor

\footnotetext{
${ }^{36}$ TRACC - Taxi Routing for Aircraft: Creation and Controlling - Légijármü gurulási útvonalának létrehozása és felügyelete

${ }^{37}$ A-CDM - Airport Collaborative Decision Making - Repülőtéri közös döntéshozatal

${ }^{38}$ Beyond visual line of sight - Látótávolságon túli
} 
szállításra, autonóm biztonsági megfigyelésekre, és mezőgazdasági felhasználásokra gondolni. A Roland Berger előrejelzése alapján 2025-re megközelítőleg 27000 napi repüléssel kell számolni Magyarországon. Nem csak a mennyiség, de a repülések trajektóriáinak komplexitása is eltér a légiforgalmi irányításban megszokottól, mivel ezek az eszközök képesek hirtelen irányt változtatni, megállni, ráadásul az alacsony légtérben dinamikusan változó környezeti elemeket is figyelembe kell venni. Könnyen belátható, hogy a drónok menedzselése és légiforgalmi irányításba történő integrálása már nem megoldható a mai eszközök és emberi erőforrás segítségével. Szükséges egy olyan pilóta nélküli légijármürendszerek forgalmi menedzsmentjét biztosító rendszer $\left(\mathrm{UTM}^{39}\right)$ kiépítése és üzemeltetése, ami önállóan alkalmas a drónok hatékony és biztonságos kezelésére. Egy ilyen ökoszisztéma pedig elképzelhetetlen mesterséges intelligencia nélkül. Szükség lesz stratégiai konfliktus menedzsmentre, dinamikus útvonaltervezésre és konfliktusok detektálásra, és azok megoldására, ráadásul minderre valós időben kell képesnek lenni [47] [48] [49].

\section{Iparági szereplök megoldásai}

Számos ATM iparágban tevékenykedő vállalat alkalmaz mesterséges intelligencia alapú megoldásokat vagy végez kutatásokat a témában jövőbeni felhasználási lehetőségükről. A brit ANSP, a NATS például 2017 márciusa óta használ egy olyan előrejelző alkalmazást a londoni TMA-ban, amely előre figyelmezteti a légiforgalmi irányítókat, ha nagy valószínűség szerint valamilyen potenciális konfliktust megelőző beavatkozás szükséges. A gépi tanuláson alapuló algoritmusuk olyan biztonságkritikus események bekövetkezésének valószínűségére ad előrejelzést, mint a level bust (kiadott magasságtól való eltérés) vagy a légtérsértések. 2015-től kezdődő valós adatokat használva a program kapcsolatot keres a veszélyhelyzetek és a forgalmi minták között (forgalomnagyság, pályairány, időjárási helyzet...), az eredmények pedig azt mutatják, hogy a 60-80\% közötti pontossággal futó rendszerben rejlenek lehetőségek [50].

Szintén a NATS tevékenységéhez köthető a Heathrow repülőtéren jelenleg még fejlesztés alatt álló kamerarendszer, ami rossz látási körülmények esetén (különösen alacsony felhőalap mellett, amikor az irányítótorony kabinja a felhőbe ér, de a pályán jók a látási viszonyok) kínál segítséget az irányítóknak és növeli meg a reptéri kapacitást. A Searidge Technologies Aimee platformján müködő, MI alapú rendszer képfelismerés útján azonosítja a futópályák szabaddá válását. Sikeres tesztek esetén elkerülhető a rossz látási viszonyok miatti jelenleg kötelező kapacitáscsökkentés, ami a világ egyik legforgalmasabb repülőterén jelentős késésekhez vezet [51].

Az Airbus is teljes mértékben elkötelezett a MI fejlesztések iránt. Csak egy pár példa a fejlesztéseik közül. A helikopterek már 2005 óta mesterséges intelligenciát használnak a forgószárnyak beállításához. Az IBM Watson segítségével olyan eddig ismeretlen összefüggéseket tártak fel, amire ember nem lett volna képes, például a hömérséklet és a fékek korai kopása közötti pontos korreláció. Képelemző algoritmusok segítségével szatellitképek alapján képesek különbséget tenni a felhők és a havazás között [52]. Mesterséges intelligencia kutatásával kapcsolatos vállalkozásoknak, kutatócsoportoknak vagy magánszemélyeknek kínál pályázati lehetőséget az Airbus AiGym programja, ahol a vállalat által szolgáltatott adatok segítségével egy meghatározott problémára kell megoldást kidolgoznia a résztvevőknek. Ennek eredménye például az a hangfelismerő technológia is, ami a repülőgépek pilótafülkéjében alkalmazva csökkentheti a pilóták munkaterhelését azáltal, hogy felismeri a rádióforgalmazásban az adott járatra

\footnotetext{
${ }^{39}$ UAS Traffic Management - Pilóta nélküli légijármürendszerek forgalmi menedzsmentjét biztosító rendszer
} 
vonatkozó információkat. A rendszer egyrészt hangból szöveggé alakítja az utasításokat, másrészt jelez, ha az adott járat hívójelét véli „kihallani” a rádiózásból. A projekt eredményességét mutatja, hogy idén már a termékfejlesztés fázisába lépett a koncepció [53].

Rendkívül sokrétủ módon használja a legújabb technológiákat a francia multinacionális vállalat, a Thales is. Megoldást nyújtanak például a légiforgalmi irányítók vagy a pilóták képzése során a teljesítmény valós idejü monitorozására, amely, mint egy „elektronikus asszisztens” értékeli az adott hallgató teljesítményét. Jelen vannak az autonóm légijármü-rendszerek fejlesztésében és a légtérbe való illesztésük megvalósítási folyamataiban is. Ezen kívül nem elhanyagolható módon az Európai Bizottság által életre hívott AI4EU ${ }^{40}$ projekt vezetője is a vállalat, amely 79 szervezet és 21 ország részvételével európai szintű mesterséges intelligencia platformot hozna létre, lehetővé téve a technológiák, alkalmazások, esettanulmányok és tudásanyag megosztását az európai piacon. Ezen kívül céljuk a MI-val foglalkozó startup vállalkozások segítése is a CENTECH inkubátorházzal közösen többek között olyan területeken, mit a drónok légtérbe illesztése és autonóm forgalmi menedzsmentje [54] [55] [56].

A NASA Ames kutatóközpontjának MI alapú megoldása a „rendellenes müködések” azonosítására összpontosít, ezzel megelőzve az esetleges kritikus hibák létrejöttét. Mivel a kereskedelmi légiközlekedés biztonsága jelenleg is nagyon magas, kevés a mintavételi lehetőség és nagy kihívást jelent azon rendellenességek megtalálása, amelyek biztonsági problémát jelenthetnek. A MI a repülési adatok között kutatva olyan mintákat is felfedezhet, amelyek akár a repülőgép konstrukciós hibájára is utalhatnak [47].

\section{Jövőbe mutató tervek}

A mesterséges intelligencia egy jelenleg is hatalmas fejlődésen keresztülmenő tudományterület. A jövőben a jelenlegi alkalmazási irányok jelentős továbbfejlesztése és gyakorlatba illesztése várható, azonban ezek időtávja eléggé kérdéses. Az aviatikában minden radikális változtatás más iparágakhoz képest lassabban megy végbe, főleg a biztonságkritikus területek, leginkább az ATM rendszerek megújítása óvatos. A fő irányvonal az egyes rendszerelemek automatizálása, az irányítói munka támogatása kell, hogy legyen. A SESAR program víziójában megjelenő trajektória-alapú ATM rendszerek paradigmaváltást hozhatnak az iparágnak és megoldást nyújthatnak a növekvő forgalom okozta kihívásokra. Azt mindenesetre fontos kiemelni, hogy minden MI alapú automatizálási kísérletet szigorú, a biztonságot szem előtt tartó kutatások kell, hogy megelőzzék. A hosszútávú tervek mindegyike, mint segédeszközzel, és nem, mint embert helyettesítő technológiával számol az automatizálás tekintetében. Az automatizálás célja az ember munkaterhelésének csökkentése kell, hogy legyen, lehetővé téve ezzel, hogy a biztonságkritikus feladatokra fókuszálhasson [18].

\section{ÖSSZEGZÉS}

A folyamatosan növekvő légiforgalom és a velejáró komplexitás, megköveteli a legfejlettebb IT megoldások alkalmazását. Összességeben elmondható, hogy egy újabb ipari forradalom kellős közepén állunk, aminek a főszereplője a MI. A fentebb említett példák segítségével szemléltettük a mesterséges intelligencia lehetséges alkalmazási területeit és felhasználását, amellyel

${ }^{40}$ AI4EU - Artificial Intelligence for European Union 
már most elősegíti a kereskedelmi repülés biztonságosabbá és hatékonyabbá válását. Viszont szeretnénk felhívni a figyelmet arra is, hogy az aviatikai szektorban a mesterséges intelligenciára nem kell szükségszerủen úgy gondolni, hogy elterjedésével felváltja az emberi munkaerőt, racionálisabb az a látásmód, hogy sokkal inkább az ember mellett, az ember munkáját és döntéseit fogja segíteni, mint egy társ. A Nasa Ames kutatás vezetője szerint: „Az aviatika világában a MI nem fogja helyettesíteni az embert. Épp ellenkezőleg, a MI és az ember tökéletesen kiegészítik egymás munkáját - ez partnerség pedig életeket menthet." Mindezek mellett az Airbus véleménye is az, hogy bár napjainkban a mesterséges intelligencia szinte minden iparágban megkerülhetetlen, szerepe mégis az emberi szakértelem kiegészítése, a döntési mechanizmusok könnyítése, ami végső soron segít csökkenteni az emberek kognitív terheltségét.

\section{FELHASZNÁLT IRODALOM}

[1] R. Agarwal, "10 Examples of Artificial Intelligence You're Using in Daily Life," 09. 2018.. [Online]. Available: https://beebom.com/examples-of-artificial-intelligence/. [Accessed 20. 03. 2019.].

[2] G. Press, "A Very Short History Of Artificial Intelligence (AI)," 2016. [Online]. Available: https://www.forbes.com/sites/gilpress/2016/12/30/a-very-short-history-of-artificial-intelligenceai/\#58a67886fba2. [Accessed 20. 03. 2019.]

[3] elementsofai.com, "Elements of AI," University of Helsinki, 2018. [Online]. Available: https://www.elementsofai.com/. [Accessed 20. 03. 2019.].

[4] B. Marr, "The Key Definitions Of Artificial Intelligence (AI) That Explain Its Importance," 2018. [Online]. Available: https://www.forbes.com/sites/bernardmarr/2018/02/14/the-key-definitions-ofartificial-intelligence-ai-that-explain-its-importance/\#15ef92274f5d. [Accessed 20. 03. 2019.].

[5] wakefly.com, "Artificial Intelligence: More than Robots," 2018. [Online]. Available: https://www.wakefly.com/blog/artificial-intelligence-more-than-robots/. [Accessed 08. 03. 2019.].

[6] C. Kumar, "Artificial Intelligence: Definition, Types, Examples, Technologies," 2018. [Online]. Available: https://medium.com/@ chethankumargn/artificial-intelligence-definition-types-examplestechnologies-962ea75c7b9b. [Accessed 13. 03. 2019.].

[7] S. Ray, "Four Types of AI," 2018. [Online]. Available: https://codeburst.io/four-types-of-ai6aab2ce57c19. [Accessed 20. 03. 2019.].

[8] A. Hintze, "Understanding the 4 Types of A.I.," 2016. [Online]. Available: https://www.rdmag.com/article/2016/11/understanding-4-types-ai. [Accessed 18. 03. 2019.].

[9] L. Z. Karvalics, "Mesterséges intelligencia - a diskurzusok újratervezésének kora," Információs Társadalom, vol. XV., no. 4., p. 18., 2015. DOI: https://doi.org/10.22503/inftars.XV.2015.4.1

[10] R. K. Agrawal, "Difference between Machine Learning, Deep Learning and Artificial Intelligence," 2018. [Online]. Available: https://medium.com/@UdacityINDIA/difference-between-machine-learning-deeplearning-and-artificial-intelligence-e9073d43a4c3. [Accessed 15. 03. 2019.].

[11] M. Dhande, "What is the difference between AI, machine learning and deep learning?," 2017. [Online]. Available: https://www.geospatialworld.net/blogs/difference-between-ai\%EF\%BB\%BF-machine-learningand-deep-learning/. [Accessed 16. 02. 2019.].

[12] P. Jeffcock, "What's the Difference Between AI, Machine Learning, and Deep Learning?," 2018. [Online]. Available: https://blogs.oracle.com/bigdata/difference-ai-machine-learning-deep-learning. [Accessed 20. 03. 2019.].

[13] J. Vincent, "This is when AI's top researchers think artificial general intelligence will be achieved," 2018. [Online]. Available: https://www.theverge.com/2018/11/27/18114362/ai-artificial-general-intelligencewhen-achieved-martin-ford-book. [Accessed 02. 03. 2019.].

[14] ubs.com, "The fourth industrial revolution," 2018. [Online]. Available: https://www.ubs.com/microsites/artificial-intelligence/en/new-dawn.html. [Accessed 10. 03. 2019.].

[15] S. Writers, "Gartner Hype Cycle: AI Will Be Everywhere In 10 Years," 2018. [Online]. Available: https://which-50.com/gartners-2018-hype-cycle-ai-will-be-everywhere-in-10-years/. [Accessed 28. 02. 2019.]. 
[16] K. Panetta, "5 Trends Emerge in the Gartner Hype Cycle for Emerging Technologies, 2018," 2018. [Online]. Available: https://www.gartner.com/smarterwithgartner/5-trends-emerge-in-gartner-hype-cyclefor-emerging-technologies-2018/. [Accessed 18. 03. 2019.].

[17] iata.org, "IATA Forecast Predicts 8.2 billion Air Travelers in 2037," 2018. [Online]. Available: https://www.iata.org/pressroom/pr/Pages/2018-10-24-02.aspx. [Accessed 19. 03. 2019.].

[18] sesarju.eu, "Artificial intelligence in air traffic management," SESAR JU, 2018. [Online]. Available: https://www.sesarju.eu/sites/default/files/documents/reports/Artificial\%20Intelligence\%20and\%20SESAR \%20FINAL.pdf. [Accessed 19. 03. 2019.].

[19] eurocontrol.int, "Strategic, pre-tactical, tactical and post-ops air traffic flow and capacity management," 2017. [Online]. Available: https://www.eurocontrol.int/service/strategic-pre-tactical-tactical-and-post-opsair-traffic-flow-and-capacity-management. [Accessed 19. 03. 2019.].

[20] J.-M. Alliot and Y. Le Fablec, Using Neural Networks to predict aircraft trajectories, 1999.

[21] M. Ghasemi Hamed et al., "Statistical prediction of aircraft trajectory: regression methods vs point-mass model," ATM Seminar, 2013.

[22] K. Tastambekov, S. Puechmorel, D. Delahaye and C. Rabut, "Aircraft trajectory forecasting using local functional regression in sobolev space," Transportation Research Part C: Emerging Technologies, vol. 39., pp. 1-22, 2014. DOI: https://doi.org/10.1016/j.trc.2013.11.013

[23] M. Ghasemi Hamed, Méthodes non-paramétriques pour la prévision d'intervalles avec haut niveau de confiance: application à la prévision de trajectoires d'avions., Thèse doctorat informatique de l'INPT, 2014.

[24] M. Hrastovec and F. Solina, "Machine learning model for aircraft performances.," in 33rd Digital Avionics Systems Conference (DASC), 2014. DOI: https://doi.org/10.1109/DASC.2014.6979541

[25] R. Alligier, D. Gianazza és N. Durand, „Machine learning and mass estimation methods for ground-based aircraft climb prediction.," IEEE Transactions on Intelligent Transportation Systems 16.6: 3138-3149, 2015. DOI: https://doi.org/10.1109/TITS.2015.2437452

[26] R. Alligier, D. Gianazza és N. Durand, „Machine learning applied to airspeed prediction during climb.,” ATM seminar 2015, 11th USA/EUROPE Air Traffic Management R\&D Seminar., 2015.

[27] F. Esther Calvo et al., "DART: A Machine-Learning Approach to Trajectory Prediction and DemandCapacity Balancing.," Seventh SESAR Innovation Days, 2017.

[28] Z. Wang, M. Liang and D. Delahaye, "Short-term 4d trajectory prediction using machine learning methods," SID 2017, 7th SESAR Innovation Days, 2017.

[29] R. Marcos, O. García-Cantú és R. Herranz, „A Machine Learning Approach to Air Traffic Route Choice Modelling,” 2018. [Online]. Available: https://arxiv.org/ftp/arxiv/papers/1802/1802.06588.pdf. [Hozzáférés dátuma: 19. 03. 2019.].

[30] R. Marcos, O. García-Cantú és R. Herranz, „Combining Visual Analytics and Machine Learning for Route Choice Prediction," Seventh SESAR Innovation Days, 28th - 30th November, 2017, Belgrade, Serbia, 2017.

[31] J. Crump, "Review of stress in air traffic control: Its measurement and effects," Aviation, Space and Environmental Medecice, 1979.

[32] P. Averty, S. Athènes, C. Collet and A. Dittmar, "Evaluating a new index of mental workload in real ATC situation using psychological measures.," Note CENA NR02-763, CENA, 2002.

[33] C. Martin, J. Cegarra and P. Averty, "Analysis of mental workload during en-route air traffic control task execution based on eye-tracking technique," in International Conference on Engineering Psychology and Cognitive Ergonomics, pages 592-597. Springer, 2011. DOI: https://doi.org/10.1007/978-3-642-21741-8_63

[34] P. Kopardekar and S. Magyarits, "Measurement and prediction of dynamic density," in Proceedings of the 5th USA/Europe Air Traffic Management R \& D Seminar, 2003.

[35] D. Gianazza, "Analysis of a workload model learned from past sector operations," SID 2017, 7th SESAR Innovation Days, 2017.

[36] D. Gianazza, "Learning Air Traffic Controller Workload from Past Sector Operations," ATM Seminar, 12th USA/Europe Air Traffic Management, D Seminar, Jun 2017, Seattle, United States, 2017.

[37] D. Gianazza and J.-M. Alliot, "Optimization of air traffic control sector configurations using tree search methods and genetic algorithms," Digital Avionics Systems Conference, Oct 2002, Irvine, United States. 1, pp 2A5-1 - 2A5-8, 2002. DOI: https://doi.org/10.1109/DASC.2002.1067912 
[38] M. Sergeeva et al., "Dynamic airspace configuration by genetic algorithm," Journal of traffic and transportation engineering (English edition), vol. 4.3, pp. 300-314, 2017. DOI: https://doi.org/10.1016/j.jtte.2017.05.002

[39] H. Helmke, J. Rataj, T. Miihlhausen, O. Ohneiser, H. Ehr, M. Kleinert, Y. Oualil and M. Schulder, "Assistant-Based Speech Recognition for A TM Applications," 11th USA/ Europe Air Traffic Management Research and Development Seminar, 2015.

[40] sesarju.eu, ,Exploring the boundaries of air traffic management, A summary of SESAR exploratory research results 2016-2018.," 2018. [Online]. Available: https://www.sesarju.eu/sites/default/files/documents/reports/ER_Results_2016_2018.pdf. [Hozzáférés dátuma: 19. 03. 2019.]. DOI: https://doi.org/10.2829/133053

[41] A. Schmidt et al., "Context-based recognition network adaptation for improving on-line asr in air traffic control," 2014 IEEE Spoken Language Technology Workshop (SLT), 2014. DOI: https://doi.org/10.1109/SLT.2014.7078542

[42] eurocontrol.int, "MALORCA - Automatic Recognition of ATC Commands using Speech and Radar Data, Presentation on TIM/ART workshop on Machine Learning and Artificial Intelligence," 2018. [Online]. Available: https://www.eurocontrol.int/sites/default/files/events/presentation/art-ws-ml-ai-07-malorcaidiap.pdf?update-0410. [Accessed 19. 03. 2019.].

[43] G. Jarry et al., "Aircraft Atypical Approach Detection using Functional Principal Component Analysis," SESAR Innovations Days 2018, 2018.

[44] digitaljournal.com, "Global Airport Runway Foreign Object Debris (FOD) Detection Systems Market Projections by 2028," 2018. [Online]. Available: http://www.digitaljournal.com/pr/4088860. [Accessed 19. 03. 2019.].

[45] J. García et al., "Optimization of airport ground operations integrating genetic and dynamic flow management algorithms," AI Communications, vol. 18.2, pp. 143-164, 2005.

[46] I. Gerdes és A. Temme, „Taxi routing for aircraft: Creation and Controlling,” The Second SESAR Innovation Days, 2012.

[47] A. Behr, "More than an auto-pilot, AI charts its course in aviation," 2018. [Online]. Available: https://arstechnica.com/information-technology/2018/12/unite-day1-1/. [Accessed 1403 2019].

[48] RolandBerger, "Magyar drónpiaci elemzés és növekedési kitekintés," Roland Berger, 2017.

[49] A. Tiburca, "AI and the future of drones," 2017. [Online]. Available: https://thenextweb.com/contributors/2017/12/01/ai-future-drones/. [Accessed 19. 03. 2019.].

[50] nats.aero, "Machine learning, Artificial Intelligence and air traffic management," 2018. [Online]. Available: https://nats.aero/blog/2018/02/machine-learning-artificial-intelligence-air-traffic-management/. [Accessed 19. 03. 2019.].

[51] nats.aero, "NATS trialling use of Artificial Intelligence at Heathrow Airport to cut delays," 2018. [Online]. Available: https://www.nats.aero/news/nats-trialling-use-artificial-intelligence-heathrow-airport-cutdelays/. [Accessed 19. 03. 2019.].

[52] Airbus, "Airbus' AIGym artificial intelligence challenge: focus on time series analysis," 2018. [Online]. Available: https://www.airbus.com/newsroom/news/en/2018/12/airbus--latest-aigym-artificialintelligence-challenge-is-focuse.html. [Accessed 11. 03. 2019.].

[53] aigym.airbus.com, „ATC Speech Recognition Challenge,” [Online]. Available: https://aigym.airbus.com/contest/5bc8313f58907f002785515d. [Hozzáférés dátuma: 19. 03. 2019.].

[54] thalesgroup.com, "CENTECH and Thales launch AI@CENTECH to boost start-ups to success in artificial intelligence," 2019. [Online]. Available: https://www.thalesgroup.com/en/canada/press-release/centechand-thales-launch-aicentech-boost-start-ups-success-artificial. [Accessed 19. 03. 2019.].

[55] thalesgroup.com, "Launch of first European artificial intelligence platform coordinated by Thales," 2019. [Online]. Available: https://www.thalesgroup.com/en/group/journalist/press-release/launch-first-europeanartificial-intelligence-platform-coordinated. [Accessed 19. 03. 2019.].

[56] N. Zazulia, "Thales is Using AI to Augment Air Traffic Management, Avionics International," 2019. [Online]. Available: https://www.aviationtoday.com/2019/01/24/thales-using-ai-augment-atm/. [Accessed 19. 03. 2019.]. 


\section{ARTIFICIAL INTELLIGENCE IN AVIATION}

The AI (Artificial Intelligence) and it's different fields, such as machine learning or deep learning, have gone through huge changes over the years. Although the principles are more than 50 years old, but today's easily accessible vast amount of data have helped them to reach all aspects of everyday's life. In the first part of our article, we would like to give a comprehensive picture about the definition, the functions and the classification of the AI, as well as describing those worldwide trends, that shape the present and the future of this field of science. In the second part we introduce the potential possibilities of the technology through aviation applications, together with the notion of the long term use and vision.

Keywords: artificial intelligence, machine learning, forecasting, SESAR, ATM, data analyses

\begin{tabular}{ll}
\hline Szarvas Dávid & Dávid Szarvas \\
Kutatás-fejlesztési szakértő & Research and Development Specialist \\
HungaroControl Magyar Légiforgalmi Zrt. & HungaroControl Hungarian Air Navigation Services \\
Üzletfejlesztési Igazgatóság & Business Development Directorate \\
Szakmai Fejlesztési Osztály & Research, Development and Simulation Department \\
david.szarvas@ @ungarocontrol.hu & david.szarvas@ hungarocontrol.hu \\
orcid.org/0000-0001-7761-9299 & orcid.org0000-0001-7761-9299 \\
\hline Tichy Roland & Roland Tichy \\
Junior kutatás-fejlesztési szakértő & Junior Research and Development Specialist \\
HungaroControl Magyar Légiforgalmi Zrt. & HungaroControl Hungarian Air Navigation Services \\
Üzletfejlesztési Igazgatóság & Business Development Directorate \\
Szakmai Fejlesztési Osztály & Research, Development and Simulation Department \\
roland.tichy@ @ungarocontrol.hu & roland.tichy@ hungarocontrol.hu \\
orcid.org/0000-0003-3198-3663 & orcid.org/0000-0003-3198-3663 \\
\hline Rohács Dániel (PhD) & Daniel Rohács (PhD) \\
Szakmai Fejlesztési Osztályvezető & Head of Research, Development and Simulation Dept. \\
HungaroControl Magyar Légiforgalmi Zrt. & HungaroControl Hungarian Air Navigation Services \\
Üzletfejlesztési Igazgatóság & Business Development Directorate \\
Szakmai Fejlesztési Osztály & Research, Development and Simulation Department \\
daniel.rohacs@ @ungarocontrol.hu & daniel.rohacs@ hungarocontrol.hu \\
orcid.org/0000-0002-4629-4417 & orcid.org/0000-0002-4629-4417 \\
\hline
\end{tabular}

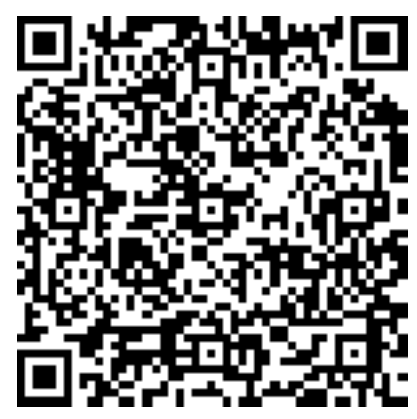

http://journals.uni-nke.hu/index.php/reptudkoz/article/view/261/44 